NiuLichen,

Postgraduate student, Sumy National Agrarian University, Sumy

\title{
RESEARCH ON ECONOMIC COMPONENT OF DYNAMIC MECHANISM OF THE FORMATION OF A FAMILY FARM IN CHINA
}

\author{
Ню Аічен \\ аспірант, Сумський національний аграрний університет, Суми \\ ORCID ID: 0000-0003-0481-846X
}

\section{АОС ІІАЖЕННЯ ЕКОНОМІЧННӦ СКАААОВОЇ АИНАМІЧНОГО МЕХАНІЗМУ ФОРМУВАННЯ СІМЕЙНОЇ ФЕРМИ В КИТАЇ}

As a new type of agricultural management subject, the emergence of family farm has been widely concerned by academic circles. Under the background of industrialization and urbanization, the development of family farm is an important strategic measure to deal with the strategic issues related to the future development of agriculture and economic society, such as the agricultural part-time industry, rural hollowing out, and the aging of farmers. It is the key point of China's agricultural policy at present. Food security, farmers' income increase and agricultural development are the key to solve the three rural issues, and also an important guarantee for economic development and social stability. With the acceleration of the urbanization process, a large number of agricultural young and middle-aged labor force continue to flow to the city. On the one hand, it leads to the relative shortage and aging of agricultural labor force, and at the same time, the commodity demand for food is also increasing. The main function of most agricultural production of traditional small-scale farmers is selfsufficiency and low agricultural commodity.

China is a country with a large population. Food security has always been a major concern of the government. food security needs to ensure food quantity security. If more than 1.3 billion people can't achieve basic selfsufficiency in food, the consequences are very serious. For the consideration of food safety, the country also urgently needs the management of the main body system of agricultural production and operation. At present, there are still about 230 million small farmers in China, accounting for more than 98\% of the main agricultural business. It is obvious that the government is unable to form effective supervision on such a large number of small farmers who operate independently. The emergence of family farms makes the land gradually concentrated to the skilled farmers. On the one hand, it reduces the number of agricultural operators, on the other hand, it will enhance the controllability of agricultural production, which is conducive to the government to strengthen the supervision of agricultural production. In 2013, family farm was defined as an important part of the new agricultural operation subject in China. With its own advantages, in recent years, it has developed rapidly and become a representative of the new scale agricult ural production organization.

Поява Сімейного фермерського господарства як нового типу сільСькогосподарського господарюючого суб'єкта знайшло широке відображення в наукових колах. На фоні індустріалізації та урбанізації розвиток сімейного фермерського господарства є важливим стратегічним заходом,дяя вирішення важАивих Питань, Пов'язаних з майбутнім розвитком сільСького господарства та економічного СУСпільСтва: СільСькогосподарське виробництво, зайнятість на неповний робочий день, занепад Сільського господарства та старіння фермерів. Нині це ключовий момент аграрної політики Китаю. Продовольча безпека, збільшення доходів фермерів та розвиток сільського господарства є кАючовими, а також є важАивою гарантією економічного розвитку та соціальної стабільності. 3 прискоренням процесу урбанізації,до міста продовЖує емігрувати велика кількість сільськогосподарської молоді та Аюдей середнього вікУ. 3 одного бокУ, це призводить до відносної нестачі та старіння сільськогосподарської робочої сили, і водночас до зростання Попиту на товари на Продукти. ОСновна характеристика більшості Сільськогосподарського виробництва традиційнихдрібних фермерів - самодостатність та низька сільськогосподарська продуктивність.

Китай - країна з великим населенням. Продовольча безпека завжди була основною турботою уряАУ, який повинен забезпечувати достатню кількість харчових продуктів. Якщо більше 1,3 мільярда Аюдей не можуть досягти необхідної самодостатності в їжі, наслідки можуть бути дуже серйозними. Аия 
формування безпеки щодо харчових продуктів країна нагально потребує вдосконалення Системи управАіння СільСькогосподарським виробництвом. Нині уКитаї б близько 230 мільйонів дрібних фермерів, що Становить понад 98\% аграрного виробництва. Очевидно, що уряд не в змозі сформувати ефективний наГАЯА за такою великою кількістю дрібних товаровиробників, які працюють самостійно. Поява сімейних господарств змушує землі поступово зосереджуватися у кваліфікованих фермерів. З одного боку, це зменшуе кількість сільСькогосподарських операторів, з іншого -це підвищує контрольованість цього секторуекономіки з боку державних органів. У 2013 році сімейне господарство було ідентифіковано як важАиву СкАадову аграрного бізнесу в Китаї. Маючи вАасні переваги, в останні роки цей спосіб господарювання Швидко розвивався і СТав вагомим компонентом в організації СУчасного СільСькогосподарСького виробництва.

Key word: institutional change, family farm, dynamic mechanism, differentiation of farmers.

Ключові слова: інституиіині зміни, сімейне господарство, динамічний механізм, диферениіачія фермерів.

\section{PROBLEM STATEMENT IN GENERAL FORM}

Since the founding of the people's Republic of China, the development of agriculture in China has gone through different stages, such as family management, cooperative movement, household contract responsibility system and so on. From 1949 to 1953 , through the land reform, the land owned by the landlords was distributed equally to the peasants to realize the privatization and self-management of the land in the unit of families. Since 1955, mutual help groups, primary cooperatives and senior cooperatives have been established in the vast rural areas, and the rural land has actually changed from private ownership of the family to collective ownership. Since 1978, the cooperatives have gradually declined The comprehensive implementation of the household contract responsibility system brings the form of household management of land back. It has been proved that the household contract responsibility system has greatly stimulated farmers' enthusiasm for production under the condition of relatively low grain output and difficult to solve the problem of food and clothing in rural areas. After that, it has shown a strong institutional advantage for quite a long time; in the new era, with the continuous transfer of agricultural labor force and the gradual improvement of agricultural production marketization and commercialization level, the institutional defects of the household contract management mode have gradually emerged, and the emergence of such restrictive factors as the decentralization of land, the primitive farming method, the weak economic and scale benefits, Objectively, it also stimulated

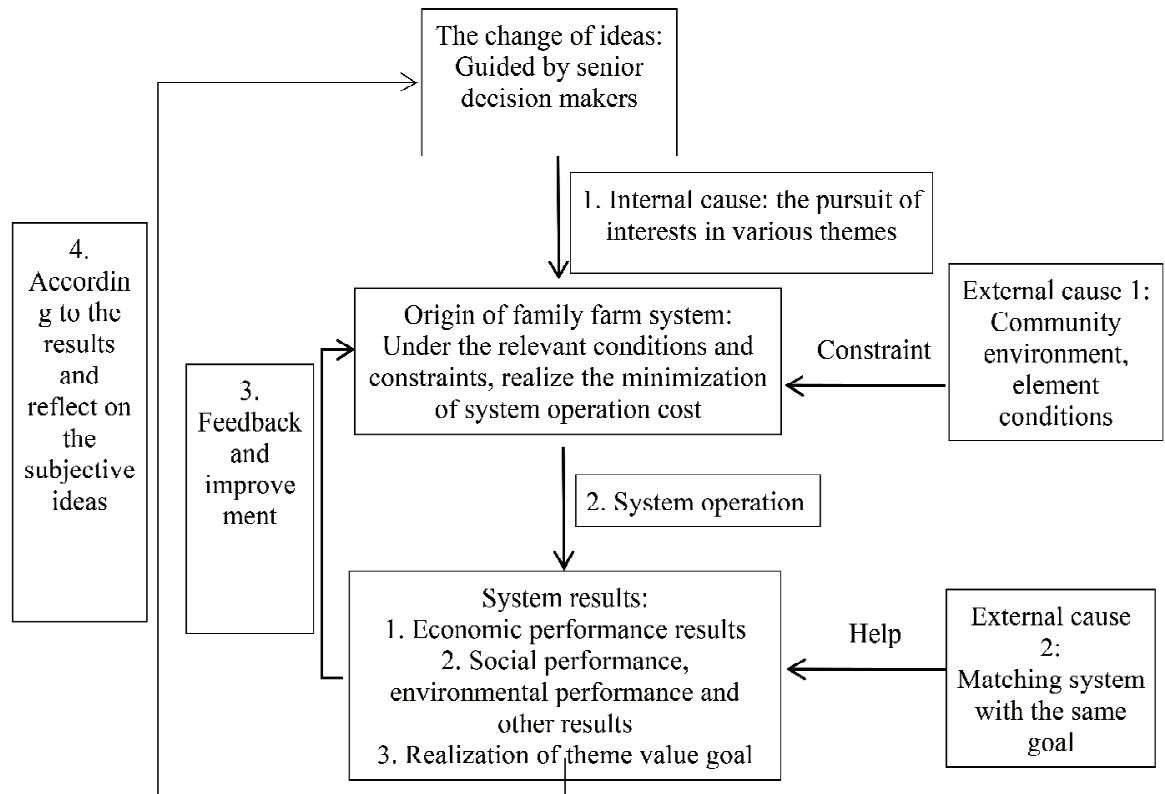

Fig. 1. The formation mechanism of the Chinese family farm the transformation and transformation of the original household based traditional small-scale agricultural management mode.

\section{IDENTIFY PREVIOUSLY UNRESOLVED PART OF THE PROBLEM}

In the process of finding new systems and new ways, it is particularly important to connect the household contract responsibility system with the market-oriented allocation mechanism of agricultural land resources. This system can not only give full play to the advantages of family management, but also bring about economies of scale, reduce transaction costs and overcome the disadvantages of small-scale agricultural economy. As a new type of agricultural management organization, family farm has emerged. It not only keeps the advantages of family management in agriculture, but also abandons the management mode of small-scale farmers. It is another innovation of the basic rural management system based on the household contract responsibility system. The rise of a new thing is bound to have the occurrence or change of the system and the generated environmental conditions. This paper will analyze the reasons for the formation of family farms from both internal and external aspects. Structure formation mechanism of the Chinese family farm (Figure 1).

\section{THE PURPOSES FORMATION} OF THE ARTICLE

There are few researches on the dynamic mechanism of the formation of family farms. The emergence of family farms is the result of their internal and external forces. This paper discusses the dynamic mechanism of the formation of family farms in China from the internal and external forces. The internal driving force includes institutional change, national and social needs and farmers' pursuit of scale efficiency and cost saving; the external driving force includes the promotion of industrialization and urbanization, the differentiation of farmers, the development of rural land transfer market and the gradual improvement of agricultural socialized service system. From the analysis, we can find out the existing problems and make suggestions for the development of family farms in China.

\section{PRESENTING THE MAIN MATERIAL (INTERNAL)}

Institutional change, national and social needs. According to the theory of 
Table 1.Support policies for family farms in major provinces or city (Data from: Functional department documents)

\begin{tabular}{|c|c|}
\hline Province & Main policy measures \\
\hline Hubei & $\begin{array}{l}\text { We will improve rural economic management and service institutions, establish rural land } \\
\text { transfer service centers, actively train farmers and provide special financial support }\end{array}$ \\
\hline $\begin{array}{l}\text { Guang } \\
\text { dong }\end{array}$ & $\begin{array}{l}\text { Innovate commercial insurance, provide financial support and reward } 100000 \text { yuan for } \\
\text { each demonstration farm. The market for the transfer of rural land. The docking between } \\
\text { farms and cooperatives will reach } 80 \%\end{array}$ \\
\hline $\begin{array}{l}\text { Shan } \\
\text { dong }\end{array}$ & $\begin{array}{l}\text { Increase financial support, establish } 1406 \text { land transfer service centers, train farmers in } \\
\text { production skills, business ability and entrepreneurship, and establish a monitoring and } \\
\text { management system for family farms }\end{array}$ \\
\hline Hebei & $\begin{array}{l}\text { Establish a federation of demonstration family farms, and provide special subsidies to } \\
\text { eligible farms }\end{array}$ \\
\hline Hunan & $\begin{array}{l}\text { Support with special funds, unify the identification and management of family farms, and } \\
\text { encourage cooperation with agricultural technology departments and family farms }\end{array}$ \\
\hline $\begin{array}{l}\text { Heilong } \\
\text { jiang }\end{array}$ & $\begin{array}{l}\text { We will develop a family farm management system, formulate measures for the } \\
\text { management of family farm identification, and implement financial subsidies }\end{array}$ \\
\hline Jiangsu & $\begin{array}{l}\text { Establish a family farm operation monitoring system, focus on supporting } 100 \text { to } 300 \mathrm{mu} \\
\text { farmers' family farms, focus on subsidizing the land transfer behavior of family farms, and } \\
\text { train tens of thousands of farmers every year }\end{array}$ \\
\hline Jilin & $\begin{array}{l}\text { Establish } 881 \text { land transfer service centers, } 874 \text { land transfer service halls and } 10 \text { million } \\
\text { yuan of special funds to build a land market covering the province }\end{array}$ \\
\hline Anhui & $\begin{array}{l}\text { With a special fund of } 40 \text { million yuan, we will carry out the identification of } \\
\text { demonstration farms, with a subsidy of } 50000 \text { yuan for each, implement policy oriented } \\
\text { agricultural insurance, } 70 \% \text { for government subsidies, } 30 \% \text { for farms, and training of } \\
\text { farmers }\end{array}$ \\
\hline Henan & $\begin{array}{l}\text { The special fund is } 430 \text { million yuan to support family farms and train more than } 5000 \\
\text { farmers }\end{array}$ \\
\hline Zhejiang & $\begin{array}{l}\text { Develop a unified circulation contract. The land circulation service organization shall be } \\
\text { established in an all-round way, and the demonstration farm shall be established }\end{array}$ \\
\hline Sichuan & $\begin{array}{l}\text { The policy guides to promote the cooperation and union of farmers, standardize the } \\
\text { registration and guarantee the rights and interests of land circulation }\end{array}$ \\
\hline Jiangxi & $\begin{array}{l}\text { We will strengthen policy guidance, improve the registration system, and set up special } \\
\text { support funds }\end{array}$ \\
\hline Fujian & $\begin{array}{l}\text { Provide } 150 \text { million yuan of special financial support each year, standardize land transfer } \\
\text { and carry out demonstration construction }\end{array}$ \\
\hline $\begin{array}{l}\text { Chong } \\
\text { qing City }\end{array}$ & $\begin{array}{l}\text { With } 10 \text { million yuan of funds, we will implement mortgage financing for rural property } \\
\text { rights, develop agricultural insurance with } 28 \text { types of insurance and } 10 \text { billion insured } \\
\text { amount, and promote the Internet }+ \text { farms }\end{array}$ \\
\hline Liaoning & $\begin{array}{l}\text { A family farm registration system will be implemented, and } 50000 \text { to } 100000 \text { yuan will be } \\
\text { awarded to the identified demonstration farms }\end{array}$ \\
\hline $\begin{array}{l}\text { Tianjin } \\
\text { City }\end{array}$ & $\begin{array}{l}\text { Set up } 131 \text { land transfer service, forming a land transfer service system and the } \\
\text { government established Agricultural Investment Guarantee Co., Ltd. }\end{array}$ \\
\hline Shanxi & $\begin{array}{l}\text { Establish the family farm directory, develop the family farm information management } \\
\text { system, and establish the family farm file }\end{array}$ \\
\hline $\begin{array}{l}\text { Neimeng } \\
\text { gol }\end{array}$ & $\begin{array}{l}\text { We will introduce standards for the identification of family farms and pastures, and } \\
\text { standards for the construction of ecological family farms and pastures }\end{array}$ \\
\hline
\end{tabular}

old Board is also an employee, enjoying all the benefits of agricultural production and operation. Secondly, the seasonality of agricultural production and the freedom and flexibility of labor arrangement make labor supervision impossible. In recent years, the main reason why various kinds of farmers' cooperatives have been questioned is the lack of labor supervision. As a result, the assessment of members' contributions is too general, so the rewards for members with different contributions and abilities are difficult to be equal, which will fall into the trap of average distribution again. On the contrary, the full self-profit of family farm makes this kind of high supervision cost unnecessary. Even if supervision is needed for distribution consideration, mutual restraint and supervision among members within the limited family is simple and easy, and the cost is very small [1].

As a relatively efficient agricultural production situation in China, family farm plays a very important role in grain production and government supervision. Since the Third Plenary Session of the 17 th CPC Central Committee put forward the development of family farms in 2008, the central government and local governments at all levels have issued a number of policy documents on the development of family farms and formulated a series of specific support measures (Table 1). Through administrative regulation, the government exerts power on the establishment and operation of family farm organization, defines the nature and business scope of family farm, further clarifies the property rights of family farm, provides a stable environment for the actors who actively participate in family farm, institutional change put forward by North, the framework of institutional change mechanism for the generation of family farms is constructed. The generation process of family farms is constrained by factors, external institutional environment and transaction cost. The institutional change of family farms in China is a dynamic evolution process which is designed and promoted from top to bottom by the government and social elites, and combined with the pursuit of farmers, enterprises and other actors from bottom to top. In the process of the formation of the new system, the guidance and determination of the incentive rules and operation system in economic activities at the national legal level are indispensable, and in the process of its formation, it is also agriculture The performance of subjective needs of households.

China has a large population and needs to ensure food security. There are many ways to ensure food security, such as relying on Farmers' professional cooperatives and agricultural enterprises, but why governments at all levels seem to focus on family farms in recent years. The main reasons are as follows: first of all, family farms are based on farmers and families, and the main labor force is members of the family. Even if there are occasional employees, they are small and phased. Compared with state-owned large farms, agricultural cooperatives and all kinds of agricultural enterprises, workers in the form of family farms are more active and efficient, because family members are actually

\section{and effectively promotes the spread of family farm.}

Farmers' pursuit of scale efficiency and cost saving. For a long time, China's population is large and land is small, which makes farmers' agricultural operation scale small and the output small for everyone [2]. According to the relevant data of the Ministry of agriculture and rural areas, at present, everyone has land of farmers in China is about $1.3 \mathrm{mu}$, with less than $10 \mathrm{mu}$ per household and distributed in different plots. Therefore, the management scale of an ordinary peasant household is between $4 \mathrm{mu}$ (family of 3 people) and $7 \mathrm{mu}$ (family of 5 people). Even if a family has 10 people's cultivated land, according to the principle of average distribution, the family has at most $13 \mathrm{mu}$ of land. If the average annual net income per mu is 700 yuan, the annual agricultural income of a family of 10 is less than 10000 yuan, and the average member of family is less than 1000 yuan. Therefore, too small scale of agricultural operation will inevitably make the operation ability of agricultural workers unable to be fully exerted, and the scale benefit will not be discussed. Through the land transfer, the cultivated land should be moderately concentrated to the farmers and families who have the willingness to agricultural production, which is not only conducive to giving full play to the intensive advantage and realizing the scale economy; at the same time, the continuous concentration of cultivated land also makes the extension of improved varieties, application of agricultural technology and mechanized 


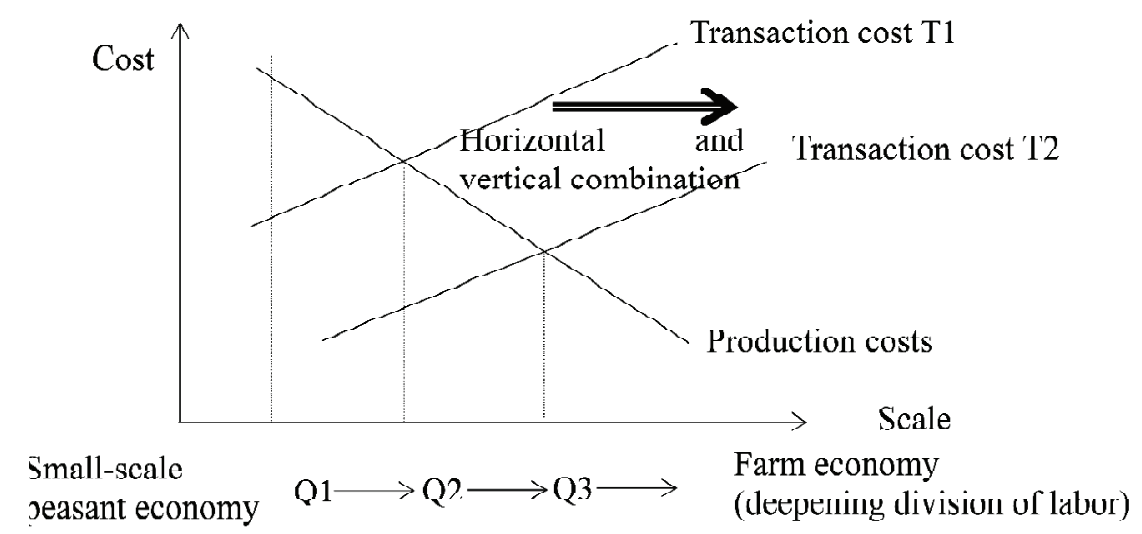

Fig. 2. The trend of the transition from small-scale peasant economy to farm economy

Table 2. China's urbanization in 2009-2018

\begin{tabular}{|l|l|l|l|l|l|}
\hline Year & $\begin{array}{c}\text { Total } \\
\text { population }\end{array}$ & $\begin{array}{c}\text { Urban } \\
\text { population }\end{array}$ & $\begin{array}{c}\text { New urban } \\
\text { population }\end{array}$ & $\begin{array}{c}\text { Urbanization } \\
\text { rate }\end{array}$ & $\begin{array}{c}\text { Growth } \\
\text { rate }\end{array}$ \\
\hline 2009 & 133450 & 62174.36 & 1214.40 & 46.59 & 0.91 \\
\hline 2010 & 134091 & 63693.23 & 982.73 & 45.68 & 0.74 \\
\hline 2011 & 134735 & 69078.63 & 5079.51 & 51.27 & 3.77 \\
\hline 2012 & 135404 & 71181.88 & 1760.25 & 52.57 & 1.3 \\
\hline 2013 & 136072 & 73070.66 & 1537.61 & 53.7 & 1.13 \\
\hline 2014 & 136782 & 74915.50 & 1463.57 & 54.77 & 1.07 \\
\hline 2015 & 137462 & 77116.18 & 1828.24 & 56.1 & 1.33 \\
\hline 2016 & 138271 & 79298.42 & 1728.39 & 57.35 & 1.25 \\
\hline 2017 & 139008 & 81347.48 & 1626.39 & 58.52 & 1.17 \\
\hline 2018 & 139539 & 83137.69 & 1790.21 & 59.58 & 1.06 \\
\hline
\end{tabular}

Data from: www.baidu.com

operation possible, and speeds up the process of agricultural modernization. With the rising price of labor relative to land resources, out of the pursuit of scale economy, farmers with farming preference are eager to get more farmland to give full play to their labor capital.

When a new institutional arrangement is in line with the current reality, the motivation of farmers to choose a new system will be enhanced. As shown in Figure 2, Q1 represents the traditional small-scale agricultural operation stage in China, which is characterized by small scale, self-sufficiency, low commodity rate, less active participation of farmers in market transactions and low transaction cost. Meanwhile, the labor production efficiency is extremely low, the scale is not economic, and the production cost is relatively high. With the deepening of division of labor, with the deepening of the division of labor, many young and middle-aged labor force are separated from agricultural production, the farmland is relatively concentrated, and the operation scale of farmers reaches Q2. Due to the expansion of production scale, various factors have been fully utilized, and labor productivity has been improved, which has brought about the decrease of production cost. At the same time, the expansion of scale has made operators pay more attention to the collection of market information, increase the number of active participation in market transactions, and increase the transaction cost. When the marginal saving of one kind of cost (production cost) is equal to the increase of another kind of cost (transaction cost), the optimal scale of production, namely Q2, is achieved. In order to further pursue the transaction benefits brought by the scale advantage, the farm households realize the internalization of external transactions and further reduce the transaction cost through "vertical" or "horizontal" cooperation. The farmers push the production scale to a higher level of equilibrium, namely Q3 (Figure 2), but the larger the scale is, the better. When the operation scale exceeds the carrying capacity of family members, the management cost will be brought And a significant increase in the cost of employee supervision. Therefore, appropriate scale family farm is the institutional choice of farmers with comparative advantage.

\section{PRESENTING THE MAIN MATERIAL (EXTERNAL)}

Industrialization and urbanization. Looking at the development process of urbanization in the past decade, the level of urbanization in China has increased from $46.59 \%$ in 2009 to $59.58 \%$ in 2018 (Table 2). Urbanization is the inevitable result of the development of industrialization to a certain stage. Industrialization affects urbanization by stimulating employment, increasing income, changing land form and so on. City is the best carrier for the development of industry. Industrialization is the economic connotation of urbanization, and urbanization is the spatial manifestation of industrialization, which promotes each other. Nowadays, the continuous penetration of industrialization in all aspects of agricultural production, such as the large use of high-efficiency pesticides and fertilizers and the introduction of agricultural mechanization equipment, has led to the increase of agricultural productivity and the continuous decline of labor input and labor intensity per unit area, resulting in the surplus of agricultural labor, which urgently needs to find new employment opportunities.

At the same time, in the process of industrialization and urbanization, it is inseparable from the penetration of various elements, especially the infrastructure construction, which will require a large number of manpower. With the gradual opening of the household registration system, population mobility and migration become possible. Many agricultural population enter the city in the process of urbanization and industrialization, seeking development. Urban employment and agricultural labor are facing different reward incentives The income of urban migrant workers is much higher than that of rural migrant workers. This obvious economic incentive difference has formed a strong attraction for agricultural labor, and the surplus agricultural labor also has employment channels. Industrialization and urbanization give impetus to agriculture, which objectively "crowd out" a large number of rural surplus labor force from agriculture, and make them leave their own cultivated land temporarily, for a long time or even forever, which provides an important premise for the transfer of agricultural land and scale management [3].

The differentiation of farmers and the development of rural land transfer market. According to the income source and working condition of peasant households, they can be divided into pure peasant households, part-time peasant households and non-agricultural peasant households. The family of non-agricultural farmers has basically separated from agricultural production, and their family income no longer depends on agricultural operation, but all comes from non-agricultural employment or other operation. At present, part-time farmers are more common in rural areas, mainly manifested as young family workers go out to work, the elderly or female spouse at home to look after children and cultivate their own fields, and their agricultural output is mainly to meet the needs of family life, which is a typical "subsistence small-scale agriculture" business model. The family income is generally based on the income of migrant workers, and the income of farming is only for subsidized household. Pure peasant households mainly include two types of families: one is the middle-aged and elderly working families who live independently, the other is all kinds of professional large-scale households in rural areas, or because it is difficult to adapt to the city's working life, or because of the persistence in agriculture, they finally choose to live in rural areas and specialize in agricultural production. The income from agricultural production and 


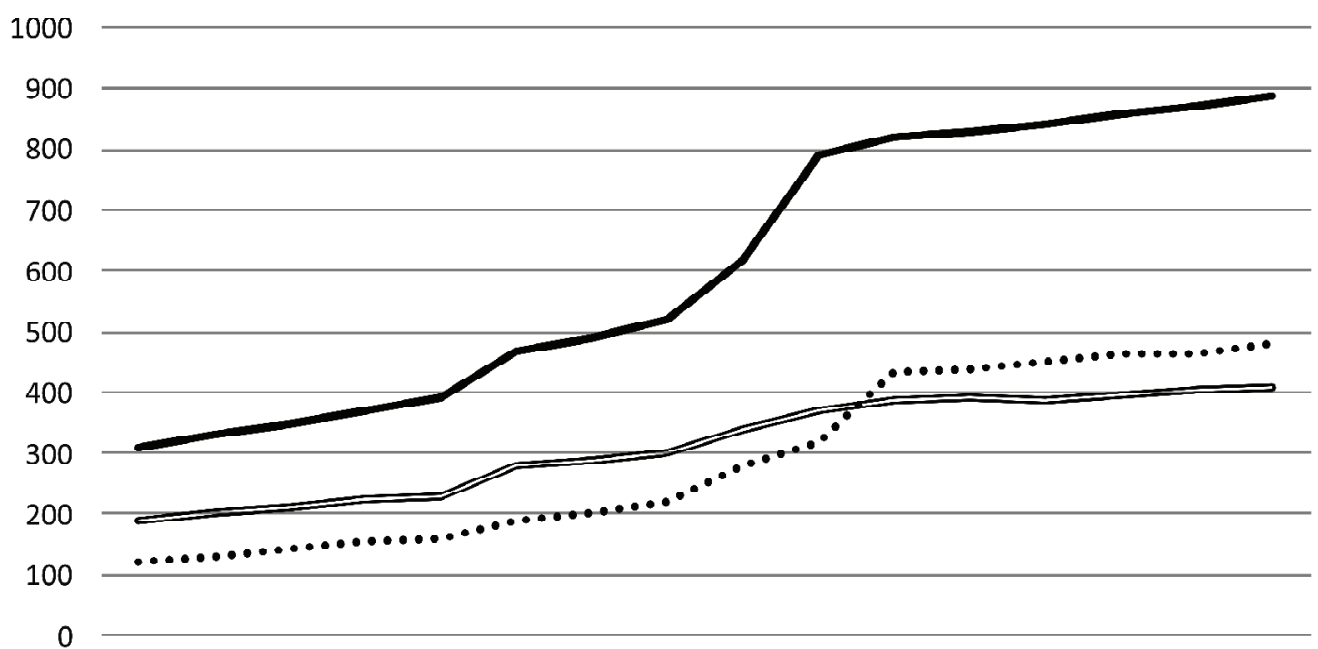

2003200420052006200720082009201020112012201320142015201620172018

$\longrightarrow$ Total cost permu Material and service fee per mu $\cdots \cdots$ Labor cost per mu

Fig. 3. Change chart of average production cost of food crops in China from 2003 to 2018 (unit: mu) (Data from: Ministry of Agriculture of China)

management is the whole source of income for the peasant households. In order to expand the scale of farming, they usually rent and plant the farmland of their relatives or neighbors who go out to work, so as to increase their farming income.

In the 1980 s and before last century, farmers going out to work was restricted by various factors. The income from farming was the main source of farmers' family income. Farmers' land was mainly cultivated by themselves, and there was almost no possibility of land transfer. After 1990, with the relaxation of floating population management and the increase of urban employment opportunities, the traditional small-scale farmers began to differentiate, and the rural land transfer market came into being. In addition, in the past 10 years, the prices of major agricultural production factors in China have risen in an all-round way, pushing agricultural production into the era of high cost. According to statistics (Figure 3 ), since 2003, the per mu production cost of wheat, corn and rice has been on the rise, especially since 2009 . The rising cost of agricultural production reduces the profit space of farmers, further intensifies the differentiation and transfer of farmers, and promotes the transformation of agricultural part-time farmers to new business entities such as family farms.

Due to the differentiation of farmers, many farmers work abroad all the year round, and generally choose to transfer their contracted land to others for cultivation. However, in the process of transfer, many transfer out households only symbolically charge a small amount of rent or leave it to their relatives or neighbors for farming. At present, there are many problems in the spontaneous land transfer among farmers, such as the transfer of land is not necessarily centralized, the transfer period is uncertain, the transfer rent is not transparent, and most of the transfer agreements are only oral agreements. In order to comply with this trend, many local governments or village collectives have creatively invented "rural land bank", "land cooperative" and other transfer platforms to regulate and guide the rational transfer and concentration of rural land, thus creating conditions for the moderate scale operation of agriculture [4]. It can be seen from figure 4 that the land transfer area in China has been on the rise (figure 4). By the end of 2018, the land transfer area in China has reached 36 million hectares, and about 68 million of the 230 million contracted land farmers in China have transferred their land. The promotion of industrialization and urbanization

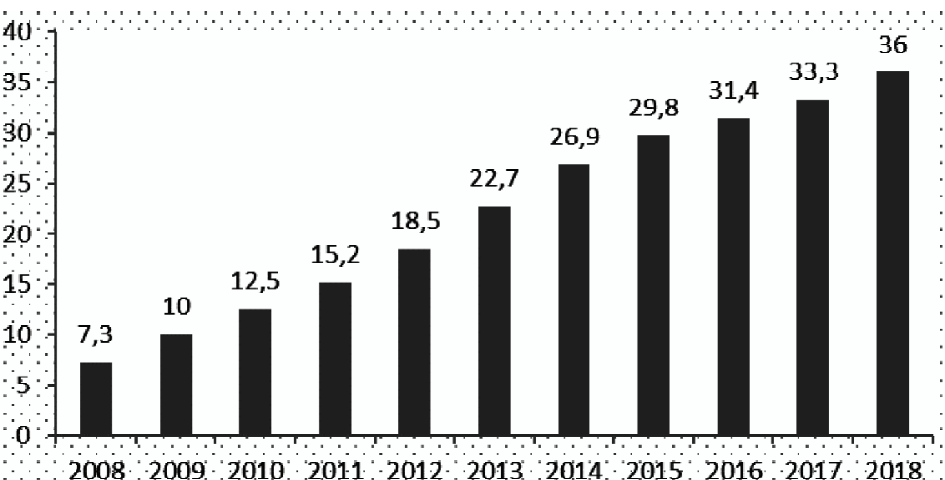

Fig. 4. China's land transfer area chart (unit: million hectares) Data from: Ministry of Agriculture of China.

provides important conditions for the development of agricultural.

The gradual development and improvement of the agricultural social service system has objectively promoted the formation of family farms. Agricultural socialized service system refers to a comprehensive network system composed of social and economic organizations related to agriculture to meet the needs of agricultural production and provide various services for the business subjects engaged in agricultural production. After the founding of the people's Republic of China, with the deepening of the movement of agricultural cooperation, China has successively established various types of agricultural technology extension institutions, supply and marketing cooperatives, rural financial institutions and other rural public service organizations. From the 1980 s to the mid-1990s, the decentralized management of farmers under the household contract responsibility system led to the contraction and decline of the original agricultural service system to some extent There are many serious problems, such as the organization, the reduction of personnel, the disrepair of meteorological and water conservancy facilities, and the brain drain of agricultural machinery service [5]. Since the beginning of the 20th century, marked by the return of the central No. 1 document to agriculture in 2003, the "three rural issues" have attracted the attention of governments at all levels Taking this as an opportunity, the agricultural socialized service system can develop and improve rapidly. After years of development, a comprehensive and systematic social service network covering the production process has 
been basically formed, with government functional and public welfare agricultural technical service institutions as the main body, and various subjects participating in it together to meet the needs of commercial agricultural development. Service functions and functions have gradually emerged and enhanced. The establishment and gradual improvement of agricultural socialized service system has made agricultural production obtain extensive external service and support, and also enabled farmers to contract some professional, technical and high-intensity production and operation links to the corresponding service agencies or brokers for compensation, so that it is possible to engage in scale management, so as to improve production efficiency and operation efficiency.

In addition, China's rural cooperative medical system has been fully covered, the operation of the endowment insurance system is increasingly perfect, farmers' dependence on land is gradually weakened, and the financial service system is also helping our family farms to solve economic difficulties. These changing environmental conditions express a strong demand for new institutional arrangements. family farm in China is under the condition of mature social economy and technology, and with the continuous opening of rural production factor market and the growing development of agricultural productive service organizations, family farms in China are gradually transformed from traditional farmers and become the leading economic subject of modern agricultural production and operation, and will contribute to China's agricultural industry in the future Powerful power [6].

\section{CONCLUSIONS AND PERSPECTIVES OF FURTHER RESEARCH}

Family farm is a kind of special institutional arrangement. Its formation is the result of the change of trading environment, the change of agricultural management mode, and the pursuit of different goals by different interest groups. Combined with the knowledge of new institutional economics, this paper draws the following conclusions through sorting out and analyzing:

The guidance of the national government and leading interest groups is the macro driving force for the formation of family farms. Among them, the internal demand for economic interests of farmers and various contractual parties is the main cause, while the change of mainstream ideas, factor conditions and institutional environment are the external factors for the generation of family farms, and the change of external environment conditions accelerates the generation and innovation of family farm system.

Reducing the transaction cost of family farms is the key to the development of family farms. The development of family farms in our country is in the primary stage. The institutional environment around family farms is still not perfect, the opportunistic behavior of farmers and contractual parties in the transaction, the adaptability of farmers to the new system and other problems lead to the high cost of the system of family farms.

The vitality of family farm lies in ensuring that the farmers who leave the land get stable employment and have high profits. The imperfect employment conditions and social security system of farmers increase the dependence of farmers on the land. If the farm operators want to obtain the land, they must pay not less than the expected income of farmers on the land, plus the increase of land, capital and technical factors due to the expansion of scale, which makes the operation of family farms face higher costs. From the perspective of opportunity cost, the minimum scale of farmers engaged in family farms should not be less than their income.

The generation of family farms is a dynamic choice process for farmers to engage in and expand agricultural scale management. If the problems caused by various constraints can be effectively eliminated and the system environment for generation can be improved, the generation power of family farms will be enhanced. On the contrary, those family farms that survive in the adverse environment may also "return" to small farmers, so the generation of family farms The driving force will be weakened.

\section{References:}

1. Gao Qiang and Liu Tongshan, (2013), "Institutional analysis of family farm", The Economist, № 6, pp. 48-56.

2. Su Xin and Wang Keshan, (2014), "Discussion on the development and scale of family farms in China based on the perspective of resource endowment ", Agricultural economic issues, № 5, pp. 8-13.

3. Guo Panpan. (2016), "Study on the dynamic mechanism and problems of family farms", Agricultural technology service, № 10 , pp. 135-136.

4. Zhu Qizhen and $\mathrm{Hu}$ Penghui, (2014), "On family farm: advantages, conditions and scale", Agricultural economic issues, № 7, pp. 11-17.

5. Qu Xueshu, "Analysis on the advantages and conditions of developing family farms in China", Economic issues, № 2, p. 106-108.

6. Cheng Lingguo, Zhang Ye and Liu Zhibiao, (2016), "Does the confirmation of farmland promote the transfer of rural land in China?", Management world, № 1, pp. 88-98. Стаття надійила до редакиії 12.02.2020 p.

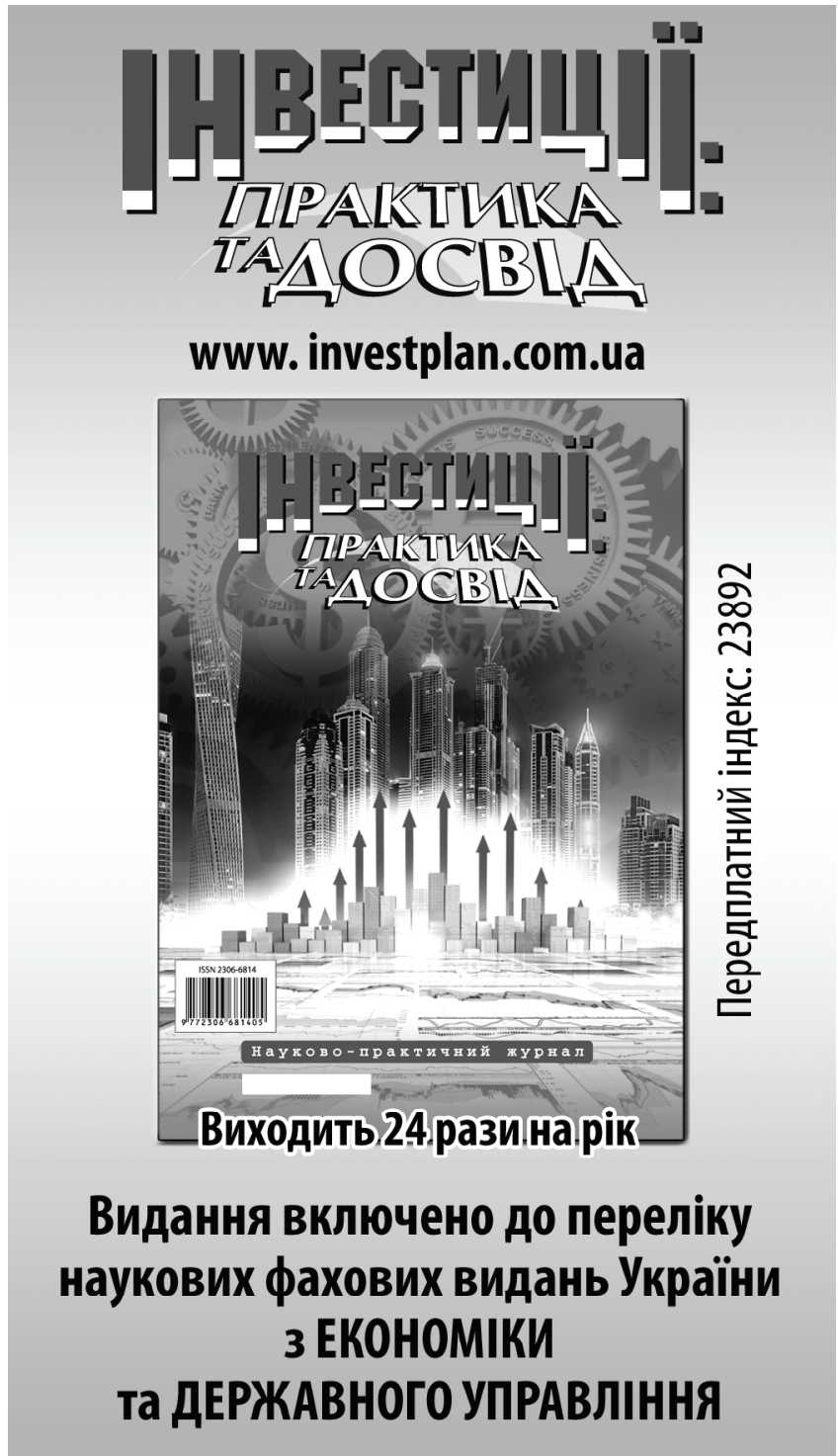

